\title{
THE INFLUENCE OF REPEATED BLOOD WITHDRAWALS BEFORE SURGERY ON CLINICAL OUTCOME
}

\author{
Helena Živná ${ }^{1}$, Pavel Živný2, Vladimír Palička ${ }^{2}$, Eva Šimáková $a^{3}$, Vít Řeháček ${ }^{4}$ \\ Charles University in Prague, Faculty of Medicine and University Hospital in Hradec Králové, Czech Republic: Radio- \\ -Isotope Laboratory and Vivarium ${ }^{1}$, Institute for Clinical Biochemistry and Diagnostics ${ }^{2}$, The Fingerland Department of \\ Pathology ${ }^{3}$, Transfusion Division ${ }^{4}$
}

Summary: The aim of this study was to find the influence of blood withdrawals and diet iron on elective surgery. Male Wistar rats ( $\mathrm{n}=24)$ were divided: 1. group (SLD) ate standard laboratory diet (SLD), 2. group (FE) an iron enriched diet (FE) with one blood withdrawal after 9 weeks. 3. group (SLD-w) SLD and 4. group (FE-w) ate the FE diet; with 9 withdrawals once a week. The rats were sacrificed 18 hour after partial hepatectomy $(\mathrm{PH})$ in the $10^{\text {th }}$ week. Liver DNA synthesis $\left({ }^{3} \mathrm{H}\right.$-thymidin $-\mathrm{kBq} / \mathrm{mg}$ DNA) was performed. Serum hepcidin $(\mathrm{pg} / \mathrm{ml})$, iron concentration, respiratory burst of polymorfonucleares (RB, spontaneous; stimulated, \%), count of blood cells were determined. FE-w had a higher $(2.36 \pm 0.36)$ liver DNA synthesis after PH vs. SLD $(1.21 \pm 0.49)$. Higher hemoglobin in erythrocytes (pg) was in FE-w and SLD-w vs. FE and SLD. PMN count in SLD-w, FE-w increased vs. SLD, FE. Hepcidin after PH decreased in SLD (78.0), FE (68.0), FE-w (97.0), but increased in SLD-w (217). Serum iron increased in SLD-w. RB after PH increased in FE-w (4.5; 47.6) vs. SLD (1.15; 29.1), FE (3.20;17.8), SLD-w (3.30;13.7). Conclusions: The iron diet with stimulation of haematopoesis by withdrawals improves an organism's condition expressed as better response to elective surgery and better PMN functions.

Key words: Preconditioning; Iron; Respiratory burst; Blood donor; rat; Elective surgery

\section{Introduction}

The matter regarding the importance of iron amount in food and its metabolic turnover in organism is not yet clear, especially concerning the repeated blood samplings from blood donors. Clinical and anamnesis data of blood donors seem to say that repeated blood samplings might improve the organism is condition, especially its immunity against infection.

Iron intestinal absorption represents only $10 \%$ of the iron needs, and the amount of iron in an organism is regulated in relation to erythropoiesis and immune system functionality (27). Generating reactive oxygen species in the respiratory burst of neutrophils is also dependent on iron (10).

Hepcidin is an antimicrobial peptide secreted mainly by the liver and plays a role in iron homeostasis (24). It inhibits intestinal iron absorption (17), placental iron transport (20), and the release of recycled iron from macrophages (21). Hepcidin could be expressed by inflammatory cells in situ (21).

The aim of this study was to prove, whether repeated blood withdrawals and a diet of enriched iron may have a positive effect on an unspecified immune system, and on the healing processes after elective surgery, when DNA synthesis after partial hepatectomy was used as a marker of the ability to oppose surgical insult.

\section{Materials and methods}

The diet was prepared by mixing two diets to obtain a suitable consistency for pellet formation. $60 \mathrm{~kg}$ of commercial powdery laboratory diet ST-1 was used (VELAS Inc., Lysa nad Labem, CZ) and $20 \mathrm{~kg}$ of defined standard laboratory diet (www.testdiet.com). There is $27 \mathrm{mg}$ of iron/kg diet (SLD). The crushed capsules of iron (ferrous sulfate, Ferronat tbl, IVAX Pharmaceutical Ltd., Opava Komarov, CZ) were mixed in the second half of the prepared diet (FE - $400 \mathrm{mg}$ of iron $/ \mathrm{kg}$ ). Both diets were fabricated into pellets and dried in $60^{\circ} \mathrm{C}$ in a food dryer.

A special committee approved the experiment protocol. All operations were performed in total ether anesthesia. Adult albino Wistar rats (Biotest Inc., Konarovice, CZ) were placed in plastic cages according to standard conditions. The rats $(n=24$, body weight $315 \pm 7 \mathrm{~g})$ were divided into 4 groups and fed on diets and drank tap water ad libitum for 9 weeks. Half of the rats (SLD) were fed with the standard laboratory diet (SLD) and drank black tea made of tap 
filtered water (filter BRITA, Germany). The other half were fed with iron enriched diet (FE) and drank common tap water. The repeated blood withdrawals $(0.5 \mathrm{ml} / 100 \mathrm{~g}$ of body weight) from retroobital plexus (w) simulated withdrawals in human blood donors.

1. group (SLD) was fed with SLD; One blood withdrawal in the $9^{\text {th }}$ week was performed. 2. group (FE) was fed with FE diet; One blood withdrawal was performed in the $9^{\text {th }}$ week. 3. group (SLD-w) was fed with SLD; where the blood withdrawal was performed once a week, i.e. 9 times together. 4. group (FE-w) was fed with the FE diet. The blood withdrawal was performed once a week, i.e. 9 times together.

The partial hepatectomy $(\mathrm{PH})$ was performed in the $10^{\text {th }}$ week in all the rats. The ${ }^{3} \mathrm{H}$-thymidine $(740 \mathrm{kBq} / 100 \mathrm{~g}$ of body weight, Lacomed Ltd., Rez u Prahy, CZ) was dosed i.v. to rats $17 \mathrm{~h}$ after $\mathrm{PH}$, and then the rats were destroyed by exsanguination from the abdominal aorta $18 \mathrm{~h}$ after $\mathrm{PH}$.

We analyzed serum iron concentrations $(\mu \mathrm{mol} / 1)$, its total binding capacity (TIBC), iron saturation (calculated) and hepcidin concentration ( $\mathrm{pg} / \mathrm{ml}$, Hepcidin pro-hormone EIA-4015, DRG, Germany). The iron concentration $(\mu \mathrm{g} / \mathrm{g}$ dry tissue) was determined in the liver tissue by atomic absorption spectrometry (Unicam Solaar 959, UK). Liver DNA synthesis was determined with methyl ${ }^{3} \mathrm{H}$-thymidine (26). The radioactivity of samples was measured on Beckman Coulter LS 6000 LL (Beckman Coulter, Fullerton, CA, USA). The DNA content of the liver was determined with diphenylamine reagent (6).

We determined in fresh heparinized blood the blood cell count, hemoglobin (HB) by Abbott CELL-DYN 3200 SL (Abbott, IL, USA) and respiratory burst of neutrophil (PMN) (28) stimulation with phorbol myristate acetate (PMA, Sigma Prague, CZ) with flow cytometric analysis (Cytomics FC500, Beckman Coulter, Fullerton, CA, USA). Positivity percentage was analyzed (CXP Analysis software, Coulter Electronic, Hialeah, FL, USA). Liver tissue for a histopathological examination was obtained from standard sites. The paraffin sections were stained for iron by potassium ferrocyanide (PENTA, Hradec Kralove, CZ). The liver iron content was evaluated according to a 0-3 arbitrary scale.

Statistical analyses were performed by software "SigmaStat 3.1 “ Jandel Scientific ${ }^{\circledR}$, San Rafael, CA, USA. One sign is $p<0.05$, two signs are $p<0.01$ and three signs are $p<0.001$. Results are expressed as mean \pm SEM. Only hepcidin and respiratory burst of PMN are expressed as median (25. and 75. percentile). Identical symbols expressed statistical significance between labelled groups.

\section{Results}

Graph 1. Serum hepcidin concentration $(\mathrm{pg} / \mathrm{ml})$

There were not any statistical notable differences in serum hepcidin concentrations among the groups before $\mathrm{PH}$. The statistical notable decrease of hepcidin concentrations after PH was in comparison before PH in SLD ( $<<0,001)$, FE $(p<0.01)$, even FE-w group $(p<0.05)$. The SLD-w group did not have any changes in its concentration in serum.

Graph 2. Respiratory burst of PMN (\%)

The spontaneous oxidative burst of PMN increased before PH in the SLD-w group versus the SLD $(p<0.01)$. The spontaneous stimulated burst increased before $\mathrm{PH}$ in the FE-w group versus FE $(p<0.05)$. The FE group had the lowest oxidative burst before PH. All groups had an in-

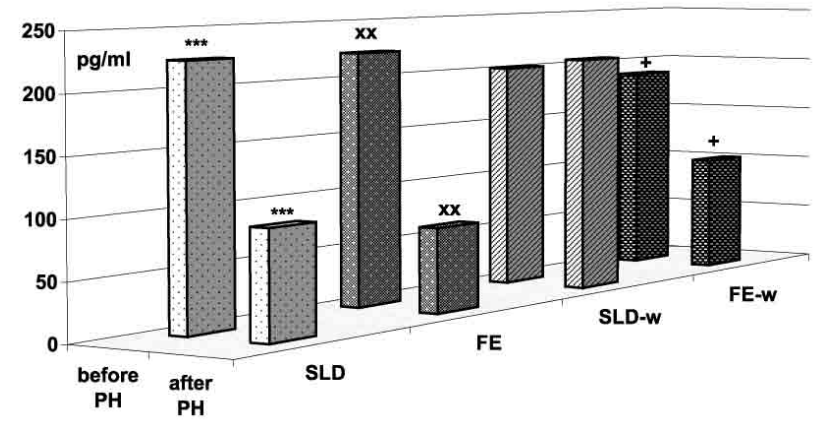

Graph 1: Serum hepcidin concentration ( $\mathrm{pg} / \mathrm{ml})$.

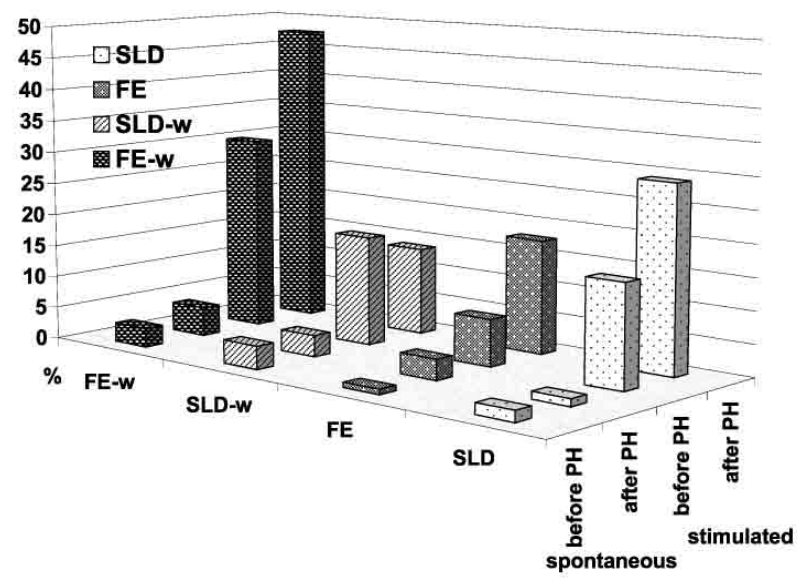

Graph 2: Respiratory burst of PMN (\%).

Tab. 1: Concentration of iron in liver, liver DNA synthesis after $\mathrm{PH}$.

\begin{tabular}{|c|c|c|c|c|c|}
\hline & \multicolumn{2}{|c|}{$\begin{array}{c}\text { Iron in liver } \\
\text { (pmol/mg) }\end{array}$} & \multicolumn{2}{c|}{$\begin{array}{c}\text { Iron content } \\
\text { in liver } \\
\text { Scale 0-3 }\end{array}$} & $\begin{array}{c}\text { s.a. liver } \\
\text { DNA } \\
(\mathrm{kBq} / \mathrm{mg} \\
\text { DNA) }\end{array}$ \\
\hline & $\begin{array}{c}\text { Before } \\
\text { PH }\end{array}$ & $\begin{array}{c}\text { After } \\
\text { PH }\end{array}$ & $\begin{array}{c}\text { Before } \\
\text { PH }\end{array}$ & $\begin{array}{c}\text { After } \\
\text { PH }\end{array}$ & $\begin{array}{c}\text { After } \\
\text { PH }\end{array}$ \\
\hline SLD & $787 \pm 162$ & $594 \pm 163$ & 0.3 & 0 & $1.21 \pm 0.49$ \\
\hline FE & $864 \pm 118$ & $780 \pm 129$ & 1 & 1.3 & $1.36 \pm 0.58$ \\
\hline SLD-w & $551 \pm 120$ & $538 \pm 123$ & 0 & 0 & $1.53 \pm 0.26$ \\
\hline FE-w & $806 \pm 60$ & $701 \pm 87$ & 0.3 & 0 & $\begin{array}{c}2.36 \pm 0.36 \\
\text { p<0.05 vs. } \\
\text { SLD }\end{array}$ \\
\hline
\end{tabular}


creased stimulated oxidative burst of PMN after $\mathrm{PH}$ in comparison to before $\mathrm{PH}$, particularly the FE-w group $(p<0.01)$ and the SLD group $(p<0.001)$, but the SLD-w group had a decrease.

\section{Table 1. Content of iron in liver, liver weight and liver DNA synthesis after $\mathrm{PH}$}

There was no statistically significant relation between higher body weight of rats and a higher liver residue weight after PH. There was also a statistical significant higher liver DNA synthesis in the FE-w group than in the SLD group.

\section{Table 2. Selected hematological parameters}

All parameters of red line decreased in all groups after $\mathrm{PH}$, where the blood withdrawals were not taken, in comparison with the values before $\mathrm{PH}$. The FE group had the highest values of hemoglobin before $\mathrm{PH}$ but also the lowest ones after PH. The blood withdrawals increased the hemoglobin content in erythrocytes in the FE-w group and particularly in the SLD-w group. Any statistical significant differences were in the number of leucocytes regarding the groups before $\mathrm{PH}$. The groups with blood withdrawals had a statistical significant increase in the absolute number of PMN after PH.

\section{Table 3. Serum iron concentrations, its binding capacity} and saturation

The SLD-w group had the highest serum iron and also the highest iron saturation before and even after $\mathrm{PH}$, and binding capacity was the lowest, and had the lowest decrease after PH. Except for the SLD-w group all groups had a statistical notable decrease in iron in the serum, saturation and even binding capacity after $\mathrm{PH}$.

\section{Discussion}

Black tea reduces iron absorption in the intestines (23), therefore we reduced the iron absorption from the diet in the SLD and SLD-w groups by black tea - our effort was to minimize iron absorption in the SLD group, when 27 $\mathrm{mg} / \mathrm{kg}$ of diet was sufficient for hematopoiesis and intensify the differences between groups.

Tab. 2: Selected hematological parameters (hemoglobin, $\mathrm{MCH}$, absolute count of leukocytes and polymorphonucleares).

\begin{tabular}{|c|c|c|c|c|c|}
\hline & & SLD & FE & SLD-w & FE-w \\
\hline \multirow[t]{2}{*}{$\mathrm{HB}(\mathrm{g} / \mathrm{l})$} & Before PH & $158 \pm 2$ & $161 \pm 1$ & $158 \pm 2$ & $156 \pm 4$ \\
\hline & After PH & $\begin{array}{c}143 \pm 4 \\
\mathrm{p}<0.01 \text { vs. SLD } \\
\text { before PH }\end{array}$ & $\begin{array}{c}140 \pm 3 \\
\mathrm{p}<0.001 \text { vs. FE } \\
\text { before } \mathrm{PH}\end{array}$ & $161 \pm 7$ & $148 \pm 3$ \\
\hline \multirow[t]{2}{*}{$\mathrm{MCH}(\mathrm{pg})$} & Before PH & $17.8 \pm 0.4$ & $17.1 \pm 0.5$ & $\begin{array}{c}19.4 \pm 0.2 \\
p<0.01 \text { vs. SLD }\end{array}$ & $\begin{array}{c}18.6 \pm 0.2 \\
p<0.05 \text { vs. FE }\end{array}$ \\
\hline & After PH & $17.6 \pm 0.4$ & $17.0 \pm 0.5$ & $19.3 \pm 0.3$ & $18.2 \pm 0.4$ \\
\hline \multirow[t]{2}{*}{ Leuko $\left(10^{9} / 1\right)$} & Before PH & $10.5 \pm 0.7$ & $10.8 \pm 0.7$ & $10.7 \pm 2.2$ & $9.9 \pm 0.4$ \\
\hline & After PH & $\begin{array}{c}6.0 \pm 0.2 \\
\mathrm{p}<0.001 \text { vs. SLD } \\
\text { before } \mathrm{PH}\end{array}$ & $8.6 \pm 1.1$ & $\begin{array}{c}6.7 \pm 0.8 \\
\mathrm{p}<0.001 \text { vs. SLD-w } \\
\text { before } \mathrm{PH}\end{array}$ & $\begin{array}{c}6.7 \pm 0.7 \\
\mathrm{p}<0.01 \text { vs.FE-w } \\
\text { before } \mathrm{PH}\end{array}$ \\
\hline \multirow[t]{2}{*}{ PMN $\left(10^{9} / 1\right)$} & Before PH & $1.00 \pm 0.35$ & $0.85 \pm 0.16$ & $1.07 \pm 0.31$ & $1.55 \pm 0.52$ \\
\hline & After PH & $1.15 \pm 0.65$ & $1.33 \pm 0.89$ & $\begin{array}{c}3.90 \pm 0.62 \\
\mathrm{p}<0.01 \text { vs.SLD-w } \\
\text { before } \mathrm{PH}\end{array}$ & $\begin{array}{c}3.90 \pm 0.56 \\
\mathrm{p}<0.01 \text { vs. FE-w } \\
\text { before } \mathrm{PH}\end{array}$ \\
\hline
\end{tabular}

Tab. 3: Serum iron concentrations, its binding capacity and saturation.

\begin{tabular}{|c|c|c|c|c|c|c|}
\hline Serum & \multicolumn{2}{|c|}{ Iron concentration $(\mathrm{mg} / \mathrm{l})$} & \multicolumn{2}{|c|}{ Saturation in serum (\%) } & \multicolumn{2}{|c|}{ Binding capacity $(\mu \mathrm{mol} / \mathrm{l})$} \\
\hline & Before PH & After PH & Before PH & After PH & Before $\mathrm{PH}$ & After PH \\
\hline SLD & $36.7 \pm 1.7$ & $\begin{array}{c}13.56 \pm 0.83 \\
\mathrm{p}<0.001 \text { vs. SLD } \\
\text { before } \mathrm{PH}\end{array}$ & $0.35 \pm 0.02$ & $\begin{array}{c}0.18 \pm 0.01 \\
\mathrm{p}<0.001 \text { vs.SLD } \\
\text { before PH }\end{array}$ & $103.7 \pm 2.7$ & $\begin{array}{c}73.4 \pm 2.4 \\
\mathrm{p}<0.001 \text { vs. SLD } \\
\text { before } \mathrm{PH}\end{array}$ \\
\hline FE & $37.3 \pm 1.1$ & $\begin{array}{c}16.45 \pm 1.52 \\
\mathrm{p}<0.001 \text { vs. FE } \\
\text { before } \mathrm{PH}\end{array}$ & $0.34 \pm 0.02$ & $\begin{array}{c}0.22 \pm 0.02 \\
\mathrm{p}<0.001 \text { vs. FE } \\
\text { before } \mathrm{PH}\end{array}$ & $109.1 \pm 3.0$ & $\begin{array}{c}76.1 \pm 3.0 \\
\mathrm{p}<0.001 \text { vs. FE } \\
\text { before PH }\end{array}$ \\
\hline SLD-w & $50.1 \pm 9.8$ & $23.67 \pm 6.26$ & $0.48 \pm 0.07$ & $0.35 \pm 0.10$ & $77.5 \pm 12.0$ & $\begin{array}{c}70.2 \pm 2.3 \\
\mathrm{p}<0.01 \text { vs.SLD-w } \\
\text { before } \mathrm{PH}\end{array}$ \\
\hline FE-w & $41.0 \pm 2.7$ & $\begin{array}{c}14.64 \pm 1.40 \\
\mathrm{p}<0.001 \text { vs. FE-w } \\
\text { before } \mathrm{PH}\end{array}$ & $0.42 \pm 0.02$ & $\begin{array}{c}0.22 \pm 0.02 \\
\mathrm{p}<0.001 \text { vs. FE-w } \\
\text { before } \mathrm{PH}\end{array}$ & $98.8 \pm 3.0$ & $\begin{array}{c}67.3 \pm 2.0 \\
\mathrm{p}<0.001 \text { vs. FE-w } \\
\text { before } \mathrm{PH}\end{array}$ \\
\hline
\end{tabular}


The parameters of erythrocytes decreased in all groups after $\mathrm{PH}$, especially in FE group, in comparison with the values before $\mathrm{PH}$. The rats fed by the iron enriched diet tolerated $\mathrm{PH}$ poorly. Repeating the blood withdrawals influenced haemapoiesis by increasing hemoglobin content in erythrocytes. The rats of the FE-w group were allowed to waste iron, and did not store it as intensively as the rats of the SLD-w group (s. iron content in liver).

The SLD-w group had the highest serum iron concentration after $\mathrm{PH}$, although without any statistical significance. This effect may cause intensive turnover of the iron available during iron insufficiency (14), or temporary ischemic periods after blood withdrawals. Hypoxia enhanced luminal iron uptake and promoted iron transfer to the blood as well (18). All groups had statistical decreases in iron, saturation and the binding capacity in serum after $\mathrm{PH}$. The SLD-w group had the lowest binding capacity even before $\mathrm{PH}$. We presume that the sufficient proteosynthesis was not supported in the course of blood withdrawals without adding the iron into the diet. We suppose that absorbed iron was not stored in serum transport proteins. The highest binding capacity of serum iron was proved in the FE group accord in results in fish living in iron enriched water (7). Iron content in liver tissue was reduced in rats by repeated blood withdrawals, whereas iron supply decreases in organisms have been proved in blood donors (11).

Hepcidin concentrations were about same in all groups before $\mathrm{PH}$, when the iron supply in all rats was sufficient. Different situation occurred after PH. The groups SLD, FE and FE-w showed a decrease in serum hepcidin concentrations after $\mathrm{PH}$, whereas the SLD-w group did not. The cause of this decrease may be the diminution of liver iron reserves and the place of hepcidin synthesis. Changes in hepcidin gene expression depend on the type and rate of insult. A decrease in hepcidin gene expression was found in rats with alcoholic liver damage (5), within 24 hours after acute anemia in mice (22) and by the third day after intravascular haemolysis (12). On the contrary, the SLD-w group, with a lower total iron supply, had a probable ischemic preconditioning with elevation of hepcidin after $\mathrm{PH}$. This result is in accordance with other authors. The elevation of liver hepcidin gene expression was proved after liver ischemia-reperfusion (13), and from 4 hour to 16 hours after $\mathrm{PH}$ in rats (25). Higher serum hepcidin concentration in the SLD-w group was preserved for giving priority to the activity of neutrophils and monocytes, which also produce hepcidin (21). Spontaneous respiratory burst was higher in the SLD-w and FE-w groups before PH, and lower in the FE group. We suppose that an iron enriched diet without blood loss has a negative effect on PMN respiratory burst, as Bergman (3) showed in phagocytosis. Respiratory burst was increased after $\mathrm{PH}$, especially in FE-w. The cause may be the inflammatory increasing of ferritin from the liver, which stimulates the superoxide production by PMN (4). Respiratory burst in SLD-w did not increase enough, particularly after stimulation by PMA, because iron supplies were low. $\mathrm{Li}$ (19) demonstrated that the functions of respiratory burst were markedly decreased in iron-deficient rats.

Healing processes were studied by means of a quantifiable marker; i.e., early initiation of liver regeneration. The FE-w group had an earlier start of liver DNA synthesis because the effect of iron enriched diet and blood withdrawals add up. The effect of iron is positive on DNA synthesis of rat hepatocytes (9). Similarly, our unpublished experimental data suggest that drinking black tea did not significantly inhibit liver DNA synthesis 18 hours after PH (1.79 \pm 0.18 $\mathrm{kBq} / \mathrm{mg}$ DNA) vs. drinking water $(2.23 \pm 0.39 \mathrm{kBq} / \mathrm{mg}$ DNA, $\mathrm{p}=0.325$ ). We assumed that this fact is a result of inhibition of intestinal iron absorption by black tea.

The blood withdrawals before PH induced a "preconditioning" state which supported liver regeneration, like hyperbaric oxygenation (15), sham operation (16), carnitine (8), or ischemic pre-conditioning (2).

\section{Conclusion}

An iron enriched diet with stimulation of haematopoesis led to better response to elective surgery (PH), expressed as earlier initiation of liver regeneration and better PMN functions. Our results support the idea of using pre-operation auto-transfusions with iron supplementation to patients.

Sponsored by Research project MZO 00179906.

\section{References}

1. Amer J, Fibach E. Chronic oxidative stress reduces the respiratory burst response of neutrophils from beta-thalassaemia patiens. British Journal of Hematology 2005;129:435-41.

2. Bedirli A, Kerem M, Pasaoglu $\mathrm{H}$ et al. Effects of ischemic preconditioning on regenerative capacity of hepatocyte in the ischemically damaged rat livers. J Surg Res 2005;125:42-8

3. Bergman M, Salman H, Pinchasi R et al. Phagocytic capacity and apoptosis of peripheral blood cells from patients with iron deficiency anemia. Biomed Pharmacother 2005;59:307-11.

4. Brailsford S, Lunec J, Winyard $P$ et al. A possible role for ferritin during inflammation. Free Radic Res Commun 1985;1:101-9.

5. Bridle K, Cheung TK, Murphy T et al. Hepcidin is down-regulated in alcoholic liver injury: implications for the pathogenesis of alcoholic liver disease. Alcohol Clin Exp Res 2006;30:106-12.

6. Burton K. A study of the condition and mechanism of the colorimetric estimation of deoxyribonucleic acid. Biochem J 1956;62:315-23.

7. Carriquiriborde P, Handy RD, Davies SJ. Physiological modulation of iron metabolism in rainbow trout (Oncorhynchus mykiss) fed low and high iron diets. J Exp Biol 2004;207:75-86.

8. Červinková Z, Kalinová M, Šimek J. The effect of carnitine on the early phase of liver regeneration after partial hepatectomy in rats with experimental diabetes. Bratisl Lek Listy 1992;93:359-63.

9. Chenoufi N, Loreal O, Drenou B et al. Iron may induce both DNA synthesis and repair in rat hepatocytes stimulated by EGF/pyruvate. J Hepatol 1997;26:650-8.

10. Dahlgren C, Karlsson A. Respiratory burst in human neutrophils. J Immunol Meth 1999;232:3-14.

11. Fernandez-Real JM, Lopez-Bermejo A, Ricart W. Iron stores, blood donation, and insulin sensitivity and secretion. Clin Chem. 2005;51:1201-5.

12. Frazer DM, Inglis HR, Wilkins SJ et al. Delayed hepcidin response explains the lag period in iron absorption following a stimulus to increase erythropoiesis. Gut 2004:53:1509-15.

13. Goss JA, Seu P, Gao FQ et al. Ischemia-reperfusion of rat liver modulates hepcidin in vivo expression. Liver Transpl 2005;11:800-6.

14. Kolb H, Kolb-Bachofen V. Nitric oxide: a pathogenetic factor in autoimmunity Immunol Today 1992;13:157-60.

15. Kurir TT, Markotic A, Katalinic V et al. Effect of hyperbaric oxygenation on the regeneration of the liver after partial hepatectomy in rats. Braz J Med Biol Res 2004;37:1231-7. 
16. Laurent S, Starkel P, Leclercq IA et al. Molecular events associated with accelerated proliferative response in rat livers when partial hepatectomy is preceded by a sham operation. Eur J Clin Invest 2005;35:140-7.

17. Lee P, Peng H, Gelbart T et al. Regulation of hepcidin transcription by interleukin-1 and interleukin-6. Proc Natl Acad Sci USA. 2005;102:1906-10.

18. Leung PS, Srai SK, Mascarenhas $M$ et al. Increased duodenal iron uptake an transfer in a rat model of chronic hypoxia is accompanied by reduced hepcidi expression. Gut 2005;54:1391-5.

19. Li Q, Liao Q, Luo C et al. Investigation of impairment of neutrophil's phagocytosis and bactericidal function in rats with iron deficiency Hua Xi Yi Ke Da Xue Xue Bao 1991;22:274-7.

20. Martin ME, Nicolas G, Hetet G et al. Transferrin receptor 1 mRNA is downregulated in placenta of hepcidin transgenic embryos. FEBS Lett 2004;574: $187-91$

21. Nemeth E, Rivera S, Gabayan V et al. IL-6 mediates hypo-ferremia of inflammation by inducing the synthesis of the iron regulatory hormone hepcidin. J Clin Invest 2004:113:1271-6.
22. Nicolas G, Viatte L, Bennoun $\mathrm{M}$ et al. Hepcidin, a new iron regulatory peptide. Blood Cells Mol Dis 2002;29:327-35.

23. O'Coinceanainn M, Bonnely S, Baderschneider B, Hynes MJ. Reaction of iron (III) with theaflavin: complexation and oxidative products. J Inorg Biochem. 2004;98:657-63.

24. Peyssonnaux C, Datta V, Cramer T, et al. HIF-1 expression regulates the bactericidal capacity of phagocytes. J Clin Invest 2005;115:1806-15.

25. Sheikh N, Batusic DS, Dudas J et al. Hepcidin and Hemojuvelin gene-expression in rat liver damage: In vivo and in vitro studies. Am J Physiol Gastrointest Liver Physiol 2006;291:G482-90.

26. Short J, Zemel R, Kanta J, Lieberman I. Stimulation of deoxyribonucleic acid synthesis in the liver parenchymal cells of the intact rats. Nature 1969;223:956-7.

27. Viatte L, Lesbordes-Brion JC, Lou DQ et al. Deregulation of proteins involved in iron metabolism in hepcidin-deficient mice. Blood 2005;105:4861-4.

28. Wilhelm J, Frydrychová M, Hezinová A et al. Production of hydrogen peroxide by peritoneal macrophages from rats exposed to subacute and chronic hypoxia. Physiol Res 1997:46:35-9.

Submitted February 2007.

Accepted May 2007.

\section{Corresponding author:}

Doc. MUDr. Helena Živná, CSc., Charles University in Prague, Faculty of Medicine in Hradec Králové, Radio-Isotope Laboratory and Vivarium, Šimkova 870, Hradec Kralové, Czech Republic, e-mail: zivna@lfhk.cuni.cz 